\title{
Author Correction: Competitive endogenous RNA is an intrinsic component of EMT regulatory circuits and modulates EMT
}

Yuwei Liu, Mengzhu Xue, Shaowei Du, Wanwan Feng, Ke Zhang, Liwen Zhang, Haiyue Liu, Guoyi Jia, Lingshuang $\mathrm{Wu}$, Xin Hu, Luonan Chen \& Peng Wang $\mathbb{B}$

Correction to: Nature Communications https://doi.org/10.1038/s41467-019-09649-1, published online 09 April 2019.

The originally published version of this Article contained an error in Figure 3. In panels D and G, the western blot lanes in the order left-to-right 'siCtrl + ctrl UTR', 'siTGFBI + ctrl UTR' and 'siTGFBI - TGFBI UTR' were incorrectly labelled in the order 'siTGFBI TGFBI UTR', siTGFBI + ctrl UTR' and 'siCtrl + ctrl UTR'. This error has now been corrected in both the PDF and HTML versions of the Article.

Published online: 20 November 2019

\footnotetext{
(c) Open Access This article is licensed under a Creative Commons Attribution 4.0 International License, which permits use, sharing, adaptation, distribution and reproduction in any medium or format, as long as you give appropriate credit to the original author(s) and the source, provide a link to the Creative Commons license, and indicate if changes were made. The images or other third party material in this article are included in the article's Creative Commons license, unless indicated otherwise in a credit line to the material. If material is not included in the article's Creative Commons license and your intended use is not permitted by statutory regulation or exceeds the permitted use, you will need to obtain permission directly from the copyright holder. To view a copy of this license, visit http://creativecommons.org/licenses/by/4.0/.
}

(c) The Author(s) 2019 